\title{
Four 'Cousins-in-Law': (1) Substantive Due Process \& State-Based Prohibition; (2) Slavery in the Federal Territory; (3) Polygamy and the Fight over Mormon Statehood; \& (4) Public School Prayer \& Bible Reading Decisions. Who Knew They Were 'Related'?"
}

\author{
Peter Karsten ${ }^{1}$ \\ ${ }^{1}$ University of Pittsburgh, United States \\ Correspondence: Peter Karsten, University of Pittsburgh, United States. E-mail: pjk2@pitt.edu
}

Received: March 25, 2015 Accepted: April 6, 2015 Online Published: August 24, 2015

doi:10.5539/jpl.v8n3p106 URL: http://dx.doi.org/10.5539/jpl.v8n3p106

\section{Introduction}

This essay compares four religious, political, and legal controversies in $19^{\text {th }}$ and early $20^{\text {th }}$ century America. Each was grounded in the sharp division between the Republican ${ }^{1}$ and Democratic Parties' perspectives on public policy, and all four were fired by religious differences involving the active use of "positive" law and judicial fiat. Several scholars have addressed the emergence in the state courts of substantive due process, as well as the fight in those courts over the use of the bible and school prayer in the public schools. But no one has noted the similar political division there, nor has anyone examined the political or religious affiliations of the state court justices who decided tests of the constitutionality of the early substantive due process cases, or those involving bible reading and school prayer. Two other related issues - the first regarding slavery in the territories; the second, regarding Mormon polygamy and Statehood - will receive briefer attention. The four issues ${ }^{2}$ constitute what this essay offers to our understanding of how religiously inspired party politics determined the outcome of these controversies in both state and federal legislatures and state and federal courts.

I begin with a well-known judicial controversy, set in the 1840 s \& ' 50 s: the emergence of substantive due process, and I relate it to state efforts to prohibit the sale of alcohol.

\section{2. "Substantive Due Process"}

This term refers to the judicial limiting of legislative and executive powers with respect to statutes affecting the use of one's property, as opposed to its traditional meaning, "procedural" due process, which concerns ways criminal defendants are to be treated procedurally in the legal process.

State constitutional changes in the 1840s led to the election of state supreme-court justices, and these courts appeared to be more willing to strike down state statutes as unconstitutional than ever before. In the process, the emergence of substantive due process was one of the fruits of this phenomenon. ${ }^{3}$ The earliest cases where such state courts advanced the substantive due process concept to strike down state statutes involved "takings" under eminent domain statutes for what would have been purely private roads or mills. ${ }^{4}$ But several of the more famous of these early instances of its use are alike in this regard: they voided state prohibition statutes. To date no one has offered sufficient explanations as to why these state court jurists took the positions they did on this

\footnotetext{
${ }^{1}$ In the case of the chronological first of these controversies, that over the recognition of "Substantive Due Process," here read: "the 'Conscience' Whig/'Know-Nothing"/Free-Soil/Proto-Republican Party."

2 I refer the reader to my Conclusion for mention of other such issues: abortion, birth control, gambling/lottery tickets, obscenity/pornography, prizefighting, and Sabbath Day businesses and mail delivery, all of which have be fought along similar religiously-inspired political lines.

${ }^{3}$ Noted by Jed Shugerman, "Economic Crisis and the Rise of Judicial Elections and Judicial Review,"123 Harvard Law Review 5 (March 2010) 1061-1150; Shugerman, The People's Courts: Pursuing Judicial Independence in America (Harvard Univ. Press, 2012).

${ }^{4}$ See Laura Inglis, "Substantive Due Process: Continuation of Vested Rights?" 52 American Journal of Legal History 459 (Oct. 2012), and Peter Karsten, "Supervising ‘the Spoiled Children of Legislation': Judicial Judgments Involving Quasi-Public Corporations in the Nineteenth Century U. S.," 41 American Journal of Legal History 315 at 325-332 (1997). And see David N. Mayer, "Substantive Due Process Rediscovered: The Rise and Fall of Liberty of Contract," 60 Mercer Law Review 563 at 585-89 (Winter 2009).
} 
issue. $^{5}$

\subsection{State Prohibition: The "Maine Law” Statutes and Ensuing State Court Litigation}

Alcohol consumption in the nineteenth century was substantially higher than it is today, prompting a steadily growing number of citizens to call for measures to limit its effects on individuals and families. There's insufficient space here to recapitulate the movement from the hortatory calls for temperance by "Washingtonians" in the first third of the $19^{\text {th }}$ century, to legislation providing "local option" for town or counties to prohibit the sale of alcohol, to the more stringent "Maine law." This much, however, is important to note: The issues were joined essentially over clear political party lines of division.

The "Conscience" Whigs (later a key component of the Republican Party) lobbied for these issues in the late 1840s and early 1850s; the Democratic Party, against them. To "Conscience" Whigs and Republicans, sin had to be confronted publicly, whether it be that of slavery, gambling, profanation of the Sabbath, polygamy, failure to teach the Bible in the public school, or the abuse of alcohol that led to harm to the individual and the family unit. Conscience Whigs and Republicans didn't claim that God had "called" on them to treat alcohol as mala in se; they simply reasoned that its abuse led to immoral ends - tragedies for individuals, families and the Greater Good. Americans spent six times as much per year on alcohol as they did on education, one Reformed Presbyterian Church leader observed, and twelve times as much as they contributed to "the spread of the Gospel." Another Presbyterian maintained that "every interest of the family, of social well-being, of education, of trade, of righteous government, and of true national prosperity demand the extinction of the liquor traffic."6

A number of the newly formed Republican Party in the mid-1850s (conceivably former members of the nativist American or "Know-Nothing" Party) spoke out against "the whiskey power, the power of the Romish hierarchy, and the power of the slave demon." Republican Benjamin Crary lampooned the first of this triumvirate: "rum and whisky: the keystone of Democracy, and the hope of our country."7 The party's voting base was largely comprised of members of evangelical faiths - that is, comprised of those embracing a profound faith that upright personal conduct consistent with Christian precepts and Biblical word should be practiced and encouraged in both the private and the public arenas. ${ }^{8}$ Congregationalist, Methodist, Presbyterian, and other evangelical church councils in the $19^{\text {th }}$ century passed resolutions, proclaiming that moral wrongs "should not be tolerated by any government. We may regulate right things, but wrong things should be suppressed." The majority of Presbyterians, Methodists and Congregationalists became Republicans. Evangelical Republicans proclaimed that it was not enough to be "a Christian on Sunday and anything else but a Christian on election day." A Christian was "obligated before God to vote as he prays." And the "duty of Christian men" was to abandon "any party...not thoroughly and unequivocally committed to the principle and practice of prohibition." This and other sound moral issues were to be "paramount to all party considerations.",

Throughout the nineteenth century this mantra continued to call the faithful to the polls. For example, President of the University of Wisconsin (and Republican) John Bascom, explained in the 1880s that public political action was necessary to secure statewide prohibition of alcohol: To yield (as Democrats sought) to the "personal rights" of a moderate drinker would be "to enable him to stand across the path of public progress, to check the

\footnotetext{
${ }^{5}$ Bruce Dierenfield comes the closest to such an explanation in The Battle over School Prayer: How Engel v Vitale Changed America (Univ. of Kansas Press, 2007) at p. 36.

6 "A Sorrowful Record," Presbyterian Banner, August 17, 1881, 1; John W. Mears, "The Grounds and Methods of the Temperance Reform," The Presbyterian Review (1881), p. 510; D. Stuart Dodge, "The Temperance Cause in the U. S.," Proceedings: Ninth General Council of the World Alliance of Reformed Churches, (1909), 389. Cf. Gary Scott Smith, The Seeds of Secularization: Calvinism, Culture, and Pluralism in America, 1870-1915 (Christian University Press, 1985).

7 Western Christian Advocate (Cincinnati), 7 June 1854, 9 May 1856, noted in Richard J. Carwardine, Evangelicals and Politics in Antebellum America (Yale Univ. Press, 1993), 250.

${ }^{8}$ I here use the term "evangelical" to describe this propensity. Most of those who wrote what came to be styled the "new political history" of nineteenth century America used the term "pietistic." See Paul Kleppner, The Cross of Culture: a Social Analysis of Midwestern Politics, 1850-1900 (Free Press, 1970); Kleppner, The Third Electoral System, 1853-1892: Parties, Voters, and Political Culture (Univ. of North Carolina Press, 1979); Richard Jensen, The Winning of the Midwest: Social and Political Conflict (Chicago, 1971); Geoffrey Blodgett,"A New Look at the Gilded Age: Politics in a Cultural Context," in Blodgett, ed., A New Look at the Gilded Age in Victorian America (Univ. of Pennsylvania Press, 1976); Richard L. McCormick, The Party Period and Public Policy: American Politics from the Age of Jackson to the Progressive Era (Oxford Univ. Press, 1986); Richard Carwardine, Evangelicals and Politics in Antebellum America (Yale Univ. Press, 1993); and James Bergquist, "'People and Politics in Transition," in Ethnic Voters and the Election of Lincoln, ed. Frederick Luebke (Univ. of Nebraska Press, 1971), 196-226.

${ }^{9}$ For the citations identifying the sources of these quotations, see Kleppner, Third Electoral System, fns. 26, 27, \& 28 on pp. 212-13, and fn.63 on p. 230 .
} 
movement of society, and so ultimately to destroy his own well-being as well as that of others." ${ }^{\prime 10}$ The Union Signal, voice of the Women's Christian Temperance Union, took the same view in 1884: "Moral force is the persuasion of the human will to act in accordance with intelligent conviction. Legal force is the compulsion of the human will when intelligence and conviction are wanting."11

Democrats disagreed. The party's supporters ${ }^{12}$ were overwhelmingly comprised of liturgical faiths - that is, faiths that emphasized confessional relations with a priest or minister, and thereafter more self-directed paths of securing salvation. Episcopalian Bishop of Fond du Lac, Wisconsin, voiced this view with regard to Prohibition: ${ }^{13}$

Sectarianism in its Puritan spirit strives to [check intemperate use of alcohol] by force, or law, or prohibition. It is a judicial mode of dealing with a moral problem. The [Episcopal] Church looks rather to the aid of moral restraint, and to the aid of grace...for great as is the evil of any fleshy sin, it often, by the shame it brings, leads to repentance, [as opposed to the prohibitionists'] spiritual sins of pride.

Similarly, the head of the German Lutheran Missouri Synod observed that it was proper to urge "abstinence as a thing out of love," than to violate "Christian freedom" by compelling it. "It is indeed easier to [obey prohibition] - with which man's law, the Devil and the flesh are satisfied, and which only serves to strengthen one's own self-righteousness - than it is to become a different person." Objecting to a steep rise in the price of liquor licenses by the Republican-dominated Indianapolis city council in 1888, the Democratic Indianapolis Sentinel editorialized that this constituted ${ }^{14}$

the exercise by the majority of the power to dictate to the minority in matters of personal right. The democratic theory of government is certainly in conflict with this policy. Democrats believe in the largest measure of personal liberty consistent with social order and the public security. They do not believe the state should usurp the function of private conscience.

Karl Marx observed in the mid-nineteenth century "Men make their own history, but not...just as they please; they...make it...under circumstances directly encountered, given, and transmitted from the past." ${ }^{15}$ This sounds like the persisting ethno-religious differences between the two major U. S. political parties from the 1850s to the 1930s, despite the emergence for some sons of potentially significant class-related issues, often "trumped" by the ethno-religious proclivities of elders and ancestors. ${ }^{16}$ William Slade, Jr., explained to William Seward in 1855 "my political principles...have come to me by inheritance." ${ }^{17}$ Another, George H. Putnam, observed that had he been old enough to vote in the 1855 prohibition referendum in Illinois, he would have done so "as all my uncles did and as I felt sure my father would have done had he been alive."18 Pennsylvania Democrat Richard Woolverton assured that state's Democratic governor, William Bigler, in 1854 that he had never voted Whig, for he "got a dislike agains[t] that party when I was young. I am now 56 years old [\&] have always Supported a dimocrat [sic] Party."19 In 1854 the Cincinnati Gazette observed "there are few stronger feelings in the American heart than that of party fealty." English Methodist minister Frederick Jobson observed this as well while travelling through the States during the 1856 election campaign: "Unflinching adherence to party is principle with them, and to forsake a party is regarded as an act of the greatest dishonor."20

The court cases of interest to us in this unit involve prohibition statutes. Hence I offer a brief summary of the statute that prohibitionist Neal Dow and his allies secured from the government of Maine in the early 1850s. Under what came to be called "the Maine law," production of all forms of alcoholic beverages were prohibited in

\footnotetext{
${ }^{10}$ Bascom, Sociology (Putnam's Sons, New York, 1887), 197; noted in Jensen, Winning of the Midwest, 191.

11 “Two Harmonious Forces," Union Signal, Vol. 10 (Sept. 25, 1884), p.8.

12 This describes particularly Democrats in the northern states. By 1877 the Republican Party in the South was moribund. An evangelical politician had to be a Democrat there if he had any chance of being elected or appointed to a legislative or judicial office.

${ }^{13}$ Richard Jensen, The Winning of the Midwest, 79.

14 Jensen, Winning of the Midwest, p.119.

${ }^{15}$ Marx, The $18^{\text {th }}$ Brumaire of Louis Bonaparte (1869 English translation), 66.

${ }^{16}$ This propensity to vote as one's fathers (and mothers) did persists, arguably, to the present day For the early twentieth century see John Shover, "Ethnicity and Religion in Philadelphia Politics, 1924-1940," American Quarterly 25 (1973), 499-515.

${ }^{17}$ Slade to Seward, October 19, 1855, William Seward Papers, Univ. of Rochester, noted in Gienapp, "Politics Seem to Enter into Everything," 54.

${ }^{18}$ George Haven Putnam, Memories of my Youth, 1844-1865 (G. P. Putnam's Sons, 1914), 55.

${ }^{19}$ Woolverton to Bigler, April 3, 1854, Bigler Papers, Historical Society of Pennsylvania.

${ }^{20}$ Cincinnati Gazette, August 21, 1854; Jobson, America and American Methodism (Virtue \& Emmins, 1857), 116-17.
} 
the state, and anyone offering such products obtained from outside of the state, ${ }^{21}$ or what was already available to them for sale, was subject to criminal penalty and the confiscation and destruction of the offending substances. Three citizens bringing information of non-compliance to their local magistrate was sufficient for a warrant to issue for a search, arrest, and eventually destruction of the illegal substances. Some of the critics of the law were Temperance men who simply opposed compulsion and regarded its support flowing from "proud-stalking reformers" and the "despotism of Party." 22

Massachusetts passed a similar statute in 1852. Vermont's legislature sent one to the electorate in 1852, adopted in 1853. Connecticut's legislature passed a "Maine law" in 1853, which was vetoed by Thomas Seymour, the Democratic governor, but reenacted by a new legislature in 1854 and signed into law by Henry Dutton, the new Whig governor. Michigan's legislature proposed such a law, ratified by its electorate in 1853, but declared unconstitutional on traditional procedural due process grounds by its court. Its legislature thereupon revised the statute to address the court's objections in 1855. Ohio's ban on "the sale of intoxicating liquors" was enacted in 1854; New York's in 1854, vetoed by its Democratic governor, but reenacted the next year and signed into law by its newly elected, proto-Republican governor. Pennsylvania created its "Maine law" in 1855, as did the New Hampshire state Assembly, which overcame two previous rejections by the state Senate. An amalgam of disaffected Whigs and Free-Soilers came together in Wisconsin as the People's Party in 1853 to pass a "Maine law." Indianans of similar political inclination created a People's Party in 1854 to enact such a law. ${ }^{23}$ (Both of these parties became Republican by 1858.) In 1855, the New Hampshire state Assembly overcame two previous rejections by the state Senate to pass a "Maine law." Iowa Whigs secured a vote on a state constitutional amendment in 1854 , adopted by the electorate in 1855 , to enable the legislature to enact one as well. ${ }^{24}$

Several state courts rendered decisions on cases questioning the constitutionality of state prohibition statutes in the 1850s. Most found these prohibition statutes acceptable under the terms of both the state and federal constitutions, though there were some strong dissenting opinions. But three courts declared them void, and provided among the very first state "substantive due process" rationales in doing so. These were Massachusetts, Indiana, and New York. ${ }^{25}$

In Fisher v McGirr (1854) Chief Justice Lemuel Shaw of the Massachusetts Supreme Judicial Court held an 1852 prohibition statue unconstitutional for violating state constitutional provisions regarding illegal searches and seizures and for the taking of private property without due process of law. ${ }^{26}$ But Shaw's court had previously upheld earlier legislative measures that were not as bold as this "Maine law," and the court would later uphold an amended version addressing this court's constitutional concerns. It is the next two chronological decisions that are generally credited with creating the substantive due process concept.

Beebe v State (1855) invalidated Indiana's "Maine law." Justice Samuel Perkins (a "staunch Democrat" since his days as editor of Wayne County's The Jeffersonian) compared the taking of liquor to the "oppression" of statutes in the past compelling property owners to pay taxes to support established state churches. He noted that Indiana had some fifty distilleries earning "half a million of dollars" that would be rendered worthless by the statute, and that "the Court knows, as a matter of general knowledge,...that the use of beer [breweries were also banned] ....is not necessarily hurtful, any more than the use of lemonade or ice cream." Writing for the majority, he declared

\footnotetext{
${ }^{21}$ Earlier efforts to ban or license the sale of alcohol imported in "original packages" from abroad or from other states was taken on appeal from three New England state decisions to the nation's Supreme Court. In License Cases 46 US 504 (1847), that court, citing Brown v Maryland, 12 Wheat. (25 US) 419 (1827), held that, while alcoholic beverages could be imported in bulk packages into a state that had banned the manufacture of such drink within the state, sale of such beverages produced within the state could properly be prohibited on public policy grounds by that state's legislature.

${ }^{22}$ Edward Payson, The Maine Law in the Balance, or An Inquiry into the Theory and Working Capacity of that Measure (Portland, Maine, 1855), 33, 56. The statute does not appear to have been put to a constitutional test that reached the Maine Supreme Court.

${ }^{23}$ James Bergquist, "People and Politics in Transition," in Ethnic Voters and the Election of Lincoln, ed. Frederick Luebke (Univ. of Nebraska Press, 1971), 196, at 224-25.

${ }^{24}$ Ernest B. Gordon, The Maine Law (Fleming Revell Co., 1919); Robert Sweirenga, "The Ethnic Voter and the First Lincoln Election," in Ethnic Voters, 136-37. And see William E. Gienapp, The Origins of the Republican Party, 1852-56 (Oxford Univ. Press, 1987), 47-60 on fights over "the Maine Law" in several state legislatures and political parties.

${ }^{25}$ For general accounts of the temperance/prohibition states and court challenges in this era see Frank Johnson \& Ruth Kessler, "The Liquor License System: Its Origins and Constitutional Development, Pt. II," 15 NYU Law Review 386 (1937-38), and William J. Novak, "Liquor and Constitution," in The People's Welfare: Law and Regulation in Nineteenth Century America (Univ. of North Carolina Press, 1996), 171-189.

${ }^{26}$ Fisher v McGirr, 1 Gray (67 Mass) 11 at 31, 34-37 (1854). A few years before, Shaw's Unitarian minister, Theodore Parker, called the "new law in Maine....an invasion of private right," but allowed that alcoholic abuse had become "so universal" that such a measure might be "the duty of the state to take care of its citizens" by banning alcoholic drink.
} 
the act void on substantive due process grounds. ${ }^{27}$

Justice Samuel Gookins (a Whig/Republican) dissented. Liquor produced evil domestic consequences and criminality, and he found Perkins' due process argument unconvincing. "It is the common pretext of communists, anti-renters, and other outlaws, that society has invaded their abstract and inalienable rights...." ${ }^{28}$ Gookins left the court in 1857, and in 1858 a now unanimous court reiterated that the act of 1855 was unconstitutional and void. ${ }^{29}$ And we have recently been made aware by Peter Argersinger that Indiana's (and Illinois's) circuit and Supreme Court judges in the mid and late nineteenth century were not merely elected in partisan fashion; they were active and important party political roles-players. ${ }^{30}$

Democratic Governor Horatio Seymour had vetoed a New York "Maine law" in 1854, but it was reenacted by the Whig/proto-Republican coalition in 1855 as "An act for the prevention of intemperance, pauperism and crime." Like most other "Maine laws," this one directed that, on complaint of three local residents, a magistrate was to grant a warrant to a constable to seize certain types of liquor prohibited by the statute. It was signed into law by the new coalition Governor Myron Clark, "an ardent dry," who had sponsored the bill vetoed by Seymour when he had been a state senator. ${ }^{31}$

James Wynehamer of Buffalo was convicted of possessing liquor for sale at his tavern, and the liquor was subsequently destroyed. On appeal, his attorney maintained that this constituted an unlawful taking of his property without due process. All eight Court of Appeals judges wrote views seriatim. Recently appointed Judge George Comstock (an Episcopalian, who ran for reelection in 1861 as a Democrat) wrote the first of the majority's 5 to 3 opinions, calling the prohibition law "one of fierce and intolerant proscription," and criticizing its provision that called for "individuals without authority" to "go forth on a roving commission" to destroy liquor "lawless." 32

I have identified the political affiliations of all of the four judges who concurred with Comstock: Judge Alexander S. Johnson, a recently-elected Democrat, quoted from U. S. Supreme Court Justice Joseph Story' Wilkinson opinion: "A fundamental maxim of a free government": that "the rights of personal liberty and private property should be held sacred." ${ }^{33}$ Judge Frederick Hubbard, another Democrat, opined, "Liquor is not a nuisance per se...."34 Judge Samuel L. Selden was elected on the "Hard" (pro-Kansas-Nebraska Act) Democratic ticket. Chief Judge Hiram Denio was appointed by Democratic Governor Horatio Seymour. ${ }^{35}$ I have identified the political background of only one of the three dissenting judges: William B. Wright ran for his seat on the court on the new "Republican" banner.

What about the courts that found these "Maine law" statutes unobjectionable? Vermont's upheld its state statute with a firm hand - that of Justice Milo Bennett (a Whig), who asked rhetorically in the course of his majority opinion what the difference was between taking action "to prevent the spread of a contagious disease which affects the body, or the spread of a moral contagion which results indirectly from the traffic and more directly from the unrestrained use of intoxicating liquors?" Chief Justice Isaac Redfield (a Democrat) dissented, critical of the statute's "obnoxious provisions" for enforcement and its "one-sidedness." ${ }^{36}$ This echoed the views of Vermont's Episcopal Bishop John Henry Hopkins who criticized the temperance and prohibition movement's

\footnotetext{
${ }^{27}$ Hugh Husband, "Samuel E. Perkins," A Judge in Politics," 28 Indiana Law Journal 106 (1952). Is there irony in the fact that Perkins, out of all Indiana's high court jurists, was the one who wrote the most opinions favoring the party with eminent domain powers in "taking" cases? See Louis Hegyi, "Note: Eminent Domain in Indiana, 1815-1865," 54 Indiana Law Journal 427 at 436-7 (1979).

${ }^{28}$ Beebe v State, 6 Ind. 501 at 505, 507, 511-13, 516, 519-22, 542-23, 548, 551 (Nov. term, 1855).

${ }^{29}$ In Howe $v$ State, 10 Ind. 423 (June term, 1858).

${ }^{30}$ Peter Argersinger, Representation and Inequality in Late Nineteenth Century America: The Politics of Apportionment (Cambridge University Press, 2012), 146, 150-53, 156-59, 223, 233, 226-27, 236-44.

${ }^{31}$ Phillip Auchampaugh, "Politics and Slavery, 1850-1860," in History of the State of New York, Vol. 7: Modern Party Battles (Columbia University Press, 1935), 78.

32 Wynehamer $v$ The People 13 NY 378 at 388, 402 (1856).

33 Wilkinson v Leland, 2 Peters 257, cited in Wynehamer, 417.

${ }^{34}$ Wynehamer, at p. 454. The Daily Observer, Utica, NY, Sept. 29, 1882, $4^{\text {th }}$ column: "He was once elected Judge of the supreme court, but being a Democrat, failed of reelection." The Daily Graphic, New York, NY, Sept. 29, 1882, p. 624: "He served...as...one of the Judges of the Court of Appeals for a brief period."

${ }^{35}$ New York's Court of Appeals, created in the state's constitution of 1847, included both elected and appointed justices, the latter rising from the lower appellate "supreme courts." See Francis Bergan, The History of the New York Court of Appeals, 1847-1932 (Columbia University Press, 1985).

${ }^{36}$ Lincoln v Smith, 27 Vt. 328 at 347-48 (1855). And see the Chief Justice's similar critique as the trial judge, reluctant to apply the “obnoxious" statute, in State v Prescott, 27 Vt. 194 at 197 (1855).
} 
claims of their cause's righteousness and piety; rather, the movement was "at war with the principles of the Gospel," for "the outward reformation of a single vice is nothing, when the heart remains unsanctified..."”77

Michigan's high court upheld its state's "Maine law" in 1855. Justice David Johnson's majority opinion began by assuring everyone that, while he and his colleagues were well aware the public division over the prohibition issue, he insisted "that we in no manner participate in this public feeling, or public expectation, and here endeavored to decide the question upon the law alone. ${ }^{38} \mathrm{He}$ and all but one of his colleagues were quite content with the statute's purpose. The legislature had seen "that intemperance was an evil." True, the defendant tavern owner had been denied the right to use his property as he wished, but this was "because by so doing, he inflict a moral injury upon society...." President Judge Abner Pratt, a Democrat who "hated abolitionism,",39 dissented: The act was "despotic," a "bold and daring invasion of private property." Pratt pulls no punches: It was for him a "pleasure" to "be able to place upon the judicial record of the state my solemn protest against...a most flagrant violation of the natural and vested rights of very many of the citizens of this state." He ranged back into a biblical and mediaeval past, including examples of the tippling habits of John Calvin and the Pilgrims, to protest the destruction of "a property right," the use of alcohol in Michigan, and observed "God forbid!" The legislature, after all, was "not omnipotent. It does not possess the unrestricted sovereign powers claimed for it by Neal Dow and his deluded followers." Pratt acknowledged the virtues in voluntary, personal temperance, but railed against "fanatical clergymen...enter[ing] the political field [to] take action as a party."

Two different appellants' attorneys told Connecticut's court in 1856 that the state's "Maine law" "deprives a man of his property without due process of law." A Whig/proto-Republican dominated court rejected both claims and upheld the statute. ${ }^{41}$

Rhode Island's supreme court was told by appellant's attorneys in two similar cases in 1858 that the New York court had correctly found that such an act there had substantively violated that state's due process clause, and that the Rhode Island court should do the same. But writing for the court, Chief Justice Samuel Ames, a Whig, used moral language similar to the dissenters in Beebe and Wynehamer and upheld the state statute. ${ }^{42}$

Iowa saw the issue play out over a decade, with a Whig legislature passing a Local Option law in 1847, a License law in 1849, and a liquor-by-the-glass prohibition law in 1851. Democrats fought back, sometimes halting further progress. Theodor Guetich, editor of Iowa's Der Demokrat, editorialized on February 21, 1852: "Reform does not flow from penal and prohibitory laws, but from the inner moral conscience of men." another Whig victory at the polls resulted in a "Maine law," approved by Iowa's newly elected Governor, James Grimes, and declared constitutional by that state's supreme court in $1855 .{ }^{44}$

Two decades later, in the 1880 s, the issue was alive there again, for the Republicans had upped the ante and managed to secure a statewide prohibition referendum. But it was declared void by Scott County District Judge Walter I. Hayes for shortcomings with regard to stipulations in the state constitution, and the Iowa supreme court affirmed this ruling, with Justice J. M. Beck dissenting. Beck had been nominated to the court by both the Republican and the Prohibition Parties. ${ }^{45}$

The Republicans counterattacked: Orlando H. Manning, Republican nominee in Iowa for Lieutenant Governor in 1883, drew "uproarious and long-continued and renewed applause" for his convention declamation: "The grand constituency behind us knows what Republicanism means. It means...a school house on every hill, and no saloon in the valley." ${ }^{46}$ Democrats responded by nominating Judge Hayes for election to the state supreme court. He lost, but ran 2,000 votes ahead of all Democratic candidates for office. ${ }^{47}$ Future Republican efforts in Iowa to

\footnotetext{
${ }^{37}$ Hopkins, The Primitive Church Compared with the Protestant Episcopal Church of the Present Day (Montpelier, 1836), 152, 387.

${ }^{38}$ This may, indeed, have been true, at least for Johnson, because he was a Democrat, a party comprised of most of those opposed to prohibition statutes like this one.

${ }^{39}$ Michigan Pioneer \& Historical Society, Vol. II, p. 278 (1908).

${ }^{40}$ People v Gallagher 3 Gibbs (4 Mich.) 244 at 247, 257, 259, 262-63, 265, 270-71, 285 (January term 1856).

${ }^{41}$ State v Brennan's Liquors, 25 Ct. 278 at 282 (1856); State v Wheeler, 25 Ct. 290 at 291 (1856).

42 State $v$ Keeran, 5 R.I. 497 at 506, 507 (1858).

43 “Die Reform liegt nicht im Straf-und-Verbotsgesetzen, sondern im moralischen Bewusstsein des Menschen."(My retranslation from that of Louis Pelzer, "The History and Principles of the Democratic Party of Iowa," 6 Iowa Journal of History \& Politics 163 at 200 (1908). And see Dan Clark, "The History of Liquor Legislation in Iowa, 1846-61," 6 Iowa Journal of History and Politics 55 (1908).

${ }^{44}$ Santo $v$ State, 2 Iowa 265 (1855).

${ }^{45}$ In Kohler \& Lange v Hill, 60 Iowa 543 (1883).

${ }^{46}$ Noted in Kleppner, Third Electoral System, 317.

${ }^{47}$ Ibid., 319-20.
} 
secure another state-wide referendum on prohibition, resulted in the election of a Democratic Governor, Horace Boies, a foe of prohibition, who observed in his inaugural address in 1889 that differences of voters' opinions on the subject depended "largely upon the customs of their fathers, the influence of [their] education and the surroundings in which they live." Hence, he maintained, such differences were not proper subjects for "sumptuary legislation." 48 By 1889 Iowa's German Lutheran and German and Irish Catholic population, traditional foes of prohibition, had turned the state's political tide. ${ }^{49}$

The political division on the subject could not have been clearer that when New Englanders voted in the mid and late 1880s on similar state referenda. Paul Kleppner has analyzed voting returns in three such states and estimated that over 95\% of Democrats in Massachusetts (1889), nearly $85 \%$ of Democrats in New Hampshire (1889), and over $63 \%$ of Democrats in Rhode Island (1886) voted against their state prohibition amendment. ${ }^{50}$

Are we seeing a pattern here? The justices who held these statutes to violate the due process clauses on substantive grounds were Democrats, members of a party that called itself "The Party of Personal Liberty." 51 The legislators who proposed these statutes, and the justices who dissented from these decisions, were northern "Conscience" Whigs who soon became Republicans, a party that called itself "The Party of Public Morality" (and was referred to as "The Puritan Party" by some of its Democratic critics).

The struggle over liquor reached the congressional level in 1890 when Republican Senator Henry Blair of Vermont introduced a prohibition amendment to the Constitution. That effort failed, but when the Supreme Court held that same year the states could not bar the sale of liquor imported from other states in "original packages" until the importer separated them from those larger units "without congressional permission," ${ }^{52}$ Congress immediately reacted with a statute sanctioning "the operation and effect of the laws of such State or Territory, enacted in the exercise of its police power to the same extent and in the same manner as though such liquids or liquors had been produced in such State or Territory and shall not be exempt therefrom by reason of being introduced therein in original packages or otherwise." ${ }^{, 53}$ The next year the Court upheld that measure in In re Rahrer. $^{54}$

There things stood until Republicans sent a prohibition amendment to the state legislatures and Republican state majorities secured its adoption in 1919. Democratic Governor of New York, Franklin Roosevelt, campaigned successfully for the presidency in 1932 with a campaign poster showing his visage and that of his running mate, John Nance Garner, with a mug of beer between them. The Democratic Congress sent an amendment repealing the prohibition amendment and Democratic legislatures swiftly adopted it in 1933.

The second and third instances of this propensity for Republicans and Democrats to fight over moral questions in legislatures and courts is not as complex, because there was only one court and one legislature involved: the U. S. Supreme Court and the Congress.

\subsection{Slavery in the Federal Territories}

One more mention of a substantive due process case, in Dred Scott v Sandford. Chief Justice Roger Brooke Taney and his six Democratic colleagues held that a Congressional statute (specifically the Missouri Compromise legislation of 1820) could not deprive slave-owners seeking to take their slave property into federal territory without due process of law. ${ }^{55}$ Both Whig appointees, Benjamin Curtis of Massachusetts and John McLean of Ohio, dissented. McLean would seek the Republican nomination for President in 1860.

Constitutional amendments to establish permanent enforcement of the Court's decision were introduced in the Congress, one by Democratic Senator Jefferson Davis of Mississippi, and in early 1861, as the secession of southern states was getting underway, moderate Republicans in the House and Senate, seeking to check the progress of southern withdrawal from the Union, proposed the "irrevocable" Corwin Amendment which, had it been adopted by enough of the state legislatures, would have been numbered as the 13th:

\footnotetext{
48 Jensen, Winning of the Midwest, 108; Clark, "Liquor Legislation," 576-77.

${ }^{49}$ On the Catholic and Lutheran population of Iowa in 1890 see fn. 115.

${ }^{50}$ Kleppner, Third Electoral System, 343.

${ }^{51}$ Kleppner, Third Electoral System, 235-36.

${ }_{52}$ Leisy $v$ Hardin, 135 US 100, at 125 1890).

${ }^{53}$ Statutes at Large, vol. 26, 313.

54140 US 545 (1891).

${ }^{55}$ Chief Justice Taney: "It is the opinion of the court that the act of Congress which prohibited a citizen from holding and owning property of this kind in the territory of the United States north of the line therein mentioned is not warranted by the Constitution, and is therefore void," Scott $v$ Sandford, 63 US 393 at 452 (1857).
} 
No Amendment shall be made to the Constitution which will authorize or give to Congress the power to abolish or interfere, within any State, with the domestic institutions thereof, including that of persons held as labor or service by the laws of said State.

Republican Representative Owen Lovejoy of Illinois was outraged. He asked, sarcastically: "Does that include polygamy, the other twin relic of barbarism?" But the Amendment passed both houses of the Congress with the necessary two-thirds majorities. In his inaugural address just two days later, incoming President Abraham Lincoln referred to it and remarked: "I have no objection to its being made express and irrevocable." The legislatures of Ohio, Maryland and Illinois approved the Amendment, but by then the seceding states had left the Union, and the Amendment fell decidedly short of adoption, or slavery in the South would have been more difficult to eradicate by law alone. ${ }^{56}$

\subsection{Polygamy, One of the "Twin Relics of Barbarism," and the Fight over the Mormon Territory's Statehood}

This brings us to another legal issue, one that may be said to allow us to segue from concern over the rights of slave-owners in the federal territories, and the ensuing debate over the 'irrevocable' Amendment to guarantee slavery in the South, to another "cousin-in-law," the fight over polygamy and Mormon statehood.

The first Republican national convention, in 1856, adopted a plank in its platform calling a ban on "the twin relics of barbarism," slavery and polygamy, in the federal territories. Democrats seemed tolerant of the Mormon practice of polygamy, chiefly because of this linkage to slavery, a "peculiar institution" prominent in Democratic political areas of strength. But Republicans had allies in most of the nation's households. Thus one Indiana Republican urged Henry Lane, the Republican speaker at a political debate where wives and daughters would be in attendance, to point out that Democrats were "soft" on polygamy: "If the women get down on [them] their days are numbered., 57

Hence a similar political division took place in the Congress over polygamy in the Mormon-dominated federal territory of Utah. In 1860 Republican congressmen equated the status of women in polygamy practices with slavery, and sought to secure legislation to end the practice. Southern, and some northern Democratic members of Congress objected to its severe measures. ${ }^{58}$ In the course of attacking Mormon polygamy, the bill's sponsor, Congressman Justin Morrill of Vermont, addressed a second issue: the Mormon defense of the institution as an exercise of their religious freedom, protected in their territory by the First Amendment's religious freedom clause. "We are told," he said, "that we must tamely submit" to "artful" claims by the Church of the Latter-Day Saints that polygamy was protected by the "free exercise" clause of the First Amendment. He and his Republican colleagues would have none of that.

With the departure of the representatives and senators of the eleven seceding states, Congress enacted an Act for the Suppression of Bigamy in 1862, making bigamy a crime in federal territories. (In the same year, with the many Democrats from the South gone, it also ended the rum ration in the U. S. Navy. California's Democratic Senator, James McDougall, denounced the measure as "a piece of illegitimate legislation," one "belonging to the present popular system of humbuggery," ${ }^{, 59}$ but the Republican legislators prevailed.)

The Suppression of Bigamy Act was not enforced during the war out of concern that the Mormons might chose to aid the Confederacy, but after the war had ended the federal attorney for the territory sought prosecutions under the act. Mormon juries and reluctant wife witnesses prevented convictions until 1875 . That conviction served as the successful test of the statute's constitutionality. ${ }^{60}$ Congress pressed harder in 1882 with the Edmunds Act, adding "unlawful cohabitation," which required a lower level of proof, as a misdemeanor punishable by a fine and six months in prison, and deprived anyone of the right to vote or hold office if they so much as professed a belief in the legitimacy of polygamy. Five years later the Edmunds-Tucker Act ordered the

\footnotetext{
${ }^{56}$ See A. Chrisopher Bryant, "Stopping Time: The Pro-Slavery and 'Irrevokable' Thirteenth Amendment," 26 Harvard Journal of Law and Public Policy, 501 (2003); Philip Martin, "Illinois Ratification of the Corwin Amendment," 15 Journal of Public Law (1966), 18-91; Alton Lee, "The Corwin Amendment in the Secession Crisis," 70 The Ohio Historical Quarterly (1961), 1-26; Harold Holzer, President-Elect: Abraham Lincoln and the Great Secession Winter of 1860-61 (Simon \& Schuster, 2008), 429.

${ }^{57}$ L. F. Maxwell to Lane, June 30, 1856, Henry S. Lane Papers, Indiana Historical Society, noted in William E. Gienapp, "Politics Seem to Enter into Everything: Political Culture in the North, 1840-1860," in Essays on American Antebellum Politics, 1840-1860, ed Gienapp, et al., (Texas A \& M Univ. Press, 1982), 17.

${ }^{58}$ Sarah Barringer Gordon, The Mormon Question: Polygamy and Constitutional Conflict in Nineteenth Century America (Univ. of North Carolina Press, 2002), 62-65, 81-82; David Sehat, The Myth of American Religious Freedom (Oxford University Press, 2011), 170-73.

${ }^{59}$ Gordon, Chapter 2, "The Twin Relic of Barbarism," in The Mormon Question. Harold Langley, Social Reform in the United States Navy, 1798-1862 (Univ. of Illinois Press, 1967), 264-69.

${ }^{60}$ Reynolds v U. S., 98 US 145 (1878).
} 
U. S. Attorney-General's seizure of the Mormon Church's property and the Church's disincorporation. A portion of its assets were seized, but those in Salt Lake City remained untouched for the time being, presumably to give the church leaders an opportunity to consider ending the practice of polygamy. The constitutionality of Edmunds-Tucker was tested before the Court in late 1889, and a decision upholding the legislation was handed down in $1890 .^{61}$

Justice Joseph Bradley, a Republican appointee, spoke for his five Republican-bred colleagues in the 6-3 decision. Bradley described the Mormon Church as a "contumacious organization" with its "nefarious system and practice, so repugnant to our laws and to the principles of civilization," and criticized Mormon international proselytizing as "a blot on our civilization." By requiring the practice of tithing, the Church had forfeited its claim to the status of a charitable organization and Congress had properly required its dissolution. ${ }^{62}$ Chief Justice Melville Fuller and Justices Stephen J. Field ${ }^{63}$ and Lucius Quintus Cincinnatus Lamar ${ }^{64}$ (all three Democrats) dissented. They allowed that Congress possessed the power to declare bigamy a felony in federal territory as well as to dissolve the Church's corporate charter, but not the power to usurp judicial authority - that is, its equitable power of cy pres - by determining what to do with the Church's assets. That was "arbitrary disposition" of funds "by judicial legislation." 65

In any event, the Late Corporation decision constituted the final blow: The Mormon Church's President Wilford Woodruff was "commanded" by "the God of heaven" to abandon polygamy, and in September the Church General Authorities presented a 356 word Manifesto to that effect to the General Conference. Federal authorities soon returned the seized assets, and Congress admitted Utah as a state. And if you were wondering, as early as the 1860 s, Mormons had overwhelmingly become members of the party friendliest to their interests: They were Democrats. ${ }^{66}$

\subsection{Public-School Prayer and Bible Reading}

The uses of the bible, prayer, and hymn singing in the public schools were contested issues well over a century before Engel v Vitale and Abington School Board v Schempp, and these practices were contested as sectarian and improper from the start. ${ }^{67}$ Some scholars have noted the numerous rulings of state supreme courts in the years from 1854 to the 1920s on the constitutionality (in several cases the unconstitutionality) of bible reading and prayer in public schools. ${ }^{68}$ But none have sought to explain those opinions with attention to any background characteristics of the various states or state justices. The specific language in some of these state constitutions varied, ${ }^{69}$ explaining some of the decisions, but in most cases the language was either identical or quite open to judicial interpretation. ${ }^{70}$

\footnotetext{
${ }^{61}$ Late Corporation of the Church of the Latter-Day Saints v U. S., 136 US 1 (1890).

${ }^{62}$ Ibid.

${ }^{63}$ Field was, like most Democrats by then, on the same page as Republicans when it came to polygamy. He authored the unanimous decision upholding the Edmunds Anti-Polygamy Act of 1882 in Davis v Beason, 133 US 333 at 342-43 (1890): "Bigamy and polygamy are crimes by the laws of all civilized and Christian countries..... They tend to destroy the purity of the marriage relation, to disturb the peace of families, to degrade woman, and to debase man. Few crimes are more pernicious to the best interests of society, and receive more general or more deserved punishment. To extend exemption from punishment for such crimes would be to shock the moral judgment of the community. To call their advocacy a tenet of religion is to offend the common sense of mankind ....Probably never before in the history of this country has it been seriously contended that the whole punitive power of the government for acts, recognized by the general consent of the Christian world in modern times as proper matters for prohibitory legislation, must be suspended in order that the tenets of a religious sect encouraging crime may be carried out without hindrance."

${ }^{64}$ Before resigning to "go south" with his Confederate comrades, Lamar had opposed the anti-polygamy bill in the Senate.

${ }^{65} \mathrm{I}$ am in agreement with, and am greatly indebted to Sarah Gordon's interpretation of events (in The Mormon Question) for much of this portion of the essay.

${ }^{66}$ In the 1890 many migrated to The People's Party ("Populist") in part because of the silver issue.

${ }^{67}$ One good corrective on the subject is R. Lawrence Moore, "Bible Reading and Nonsectarian Schooling: The Failure of Religious Instruction in $19^{\text {th }}$ Century Public Education," Journal of American History, 86 (2000), 1581-1599.

${ }^{68}$ Alvin W. Johnson, Legal Status of Church-State Relations (Univ. Of Minnesota Press, 1934); Alvin Johnson \& Frank H. Yost, Separation of Church and State in the United States (Greenwood Press, 1948); Robert Drinan, Religion, The Courts, and Public Policy (McGraw-Hill, 1963); Steven K. Green, The Bible, the School, and the Constitution: The Clash that Shaped Modern Church-State Doctrine (Oxford Univ. Press, 2011), Martha Nussbaum, Liberty of Conscience: In Defense of America's Tradition of Religious Equality (Basic Books, 2008).

${ }^{69}$ Donald E. Boles provides a good overview of the key elements of these constitutions in chapter 2 of The Bible, Religion and the Public Schools (Iowa State Univ. Press, 1961).

${ }^{70}$ By the early $20^{\text {th }}$ century some of the western states had adopted constitutions with stronger language regarding the use of "sectarian" material in classrooms. For example, Article 9, Section 10, and Article 11, Section 7, of Arizona's Constitution prohibited "any teacher" from engaging in "religious readings" or "exercises" in the public schools. And when Washington's court held bible reading unconstitutional, Justice Oscar Holcomb (an Episcopalian Democrat) noted that since the state's constitution clearly prohibited such an act, the appeal should
} 
My tally of the justices in those state courts that upheld such practices, as well as those that those that declared such practices violated clauses in their states' constitutions, indicates that they tended to be of the same political persuasions as those who wrote the decisions on the "Maine laws" noted above. ${ }^{71}$ But there were other, coincidental predictor variables present: the religion of the justices and the percentage of Catholics in the state's population.

Our story began in Massachusetts in the late 1830s with Horace Mann's prescription for public schools. As early as 1826 a Massachusetts statute required that public schools make use of the bible. A Unitarian, Mann found sound moral precepts in the Bible (perhaps Thomas Jefferson's amended version of it). As President of the Massachusetts legislature's Senate in 1836-37, and Secretary of the newly-created state Board of Education in 1837-38, he allowed that its use in the schools was warranted to foster good Christian values in youth, but insisted that its use be non-sectarian. This met with criticism from those wedded to a particular version of that book, as well as the era's Catholics, "free thinkers," old-line "Primitive" Baptists, and, Jews (regarding the "New Testament" portion of it) who sought to keep religion out of the curriculum. ${ }^{72}$

In any event, by midcentury a number of state statutes required that their public schools make use of the King-James version of the Bible (with its reference, in the original "dedication," to the Pope as "that man of sin" seeking to keep the populace in "ignorance and darkness"), and several of these statutes mandated school prayer drawn from that Bible as well. ${ }^{73}$ The Catholic Church in those states bitterly opposed these measures, for the Catholic Douay Bible was at odds with the King-James on several important doctrinal points. This Catholic opposition was greeted head-on by evangelicals. In 1870 the New Jersey Annual Conference of its Methodist Episcopal Church "Resolved, That we greatly deprecate the effort which is being made to exclude the Bible from the Public Schools of our land; and that we will do all in our power to defeat the well-defined and wicked design of this "Mother of Harlots.", 74

Maine The first case challenging a statute requiring the use of the King James version of the Bible in the public schools played out in 1854 in Maine's Supreme Court. A Jesuit priest had urged the parents of a girl in a public school to challenge the statute before the school board and in the courts. The school board's attorney argued that its use was non-sectarian, but intended to provide moral principles and good Elizabethan English. Justice John Appleton for the court found this use to be benign and within the terms and language of the state's constitution, and added that the court, in any event, was not going let the Pope with his banned-books list tell Maine's governing bodies what they might and might not use in the public schools. ${ }^{75}$

By the 1920s fourteen state courts ${ }^{76}$ had upheld the use of the King-James version of the Bible and/or school prayer in their public schools; seven ${ }^{77}$ had ruled that such practices violated their state constitutions. Most of the plaintiffs in these cases were Catholic, Jewish, or agnostic parents of school-age children. Those courts sanctioning continued use of these practices noted their agreement with Appleton's views in Donahoe v Richards in their opinions; those viewing the practices as sectarian and unconstitutional differed with Donahoe. I offer here four more examples of the former, and seven examples of the latter, the first of which was limited to the Cincinnati School Board's practice.

Ohio By the 1860s Cincinnati was a city populated by people of many different faiths, and contentious issues

\footnotetext{
have been dismissed summarily. Dearle v Frazier, 102 Wash. 369, 172 Pac 35 at 37 (1918).

${ }^{71}$ Not every one of these justice's political affiliations have as yet been determined, and of those whose political affiliation could be identified, there were some exceptions to this general pattern. But the pattern is unmistakable.

${ }^{72}$ R. B. Culver, Horace Mann and Religion in the Massachusetts Public Schools (Yale Univ. Press, 1929); Steven K. Green, The $2^{\text {nd }}$ Disestablishment: Church and State in Nineteenth Century America (Oxford Univ. Press, 2010), 252, 262-63.

${ }^{73}$ In addition, there were readers like the McGuffey, that were offensive to Catholic parents: Ruth M. Elson noted that in the mid-19 $9^{\text {th }}$ century "no theme in these schoolbooks is more universal than anti-Catholicism." Elson, Guardians of Tradition: American Schoolbooks of the $19^{\text {th }}$ Century (Univ. of Nebraska Press, 1964), 53.

${ }^{74}$ Kleppner, Third Electoral System, 212-13.

75 Donahoe v Richards, 38 Me 379 at 407 (1854).

${ }^{76}$ Those of Maine, Massachusetts, New York, Pennsylvania, Michigan, Georgia, Iowa, Kentucky, Minnesota, Kansas, Florida, Tennessee, Texas, and Colorado. James Chester, Phillip Carroll \& Thomas Burke, Religion under the State Constitutions (Brooklyn, N. Y., 1965$), 53$.

77 Those of Ohio, Wisconsin, Illinois, Nebraska, South Dakota, Louisiana, and Washington. The South Dakota case, State ex rel. Finger $v$ Weedman, 55 SD 343, 226 NW 348 (1929), was limited to whether a (Catholic) student who refused to attend daily bible readings could be expelled from school. The court held that action to be "an unconstitutional infringement of religious liberty," but limited its mandate to a grant to the parents of a writ of mandamus requiring the school board to permit the student to return to school and be excused from the bible readings. The dissenting chief justice cited Donahoe.
} 
were being fought out between Catholics and Protestants over the proper role of the public schools. ${ }^{78}$ In 1869 the city's school board, by then reflecting Cincinnati's religious diversity, voted 22 to $16^{79}$ to exclude bible reading, hymns, and "the reading of religious books" from the classrooms, in part to lure back into the public schools the over 13,000 Catholic students in parochial schools (the public school system population numbered 19,000). Unitarian minister Thomas Vickers, a school board member, voted for the resolution and organized a rally in its support along with the city's two rabbis and other supporters on September 26, 1869.

Evangelicals were outraged. A committee of opponents calling themselves "Friends of the Bible" held a rally to protest the resolution two days later. The Methodist Christian Advocate maintained that the school board's action (which had included a Catholic member's proposal to bring the Catholic schools into the public system) was "Romanist policy," seeking "the overthrow, the abolition, of the whole American scheme of Common School Education. ${ }^{" 80}$ Thirty-seven evangelical Protestants, recruited by the Friends of the Bible committee, sued.

In late November the area's three judge Superior Court heard arguments for several days, considered its response, and two months later held, by 2 to 1 , that the board had acted in violation of the law and that "the Holy Scriptures" were appropriate in the classroom. Judge Marcellus Hagans, a Methodist and founder of the city's Sunday School Union, held the board's action violated the state's constitutional declaration that "religion, morality and knowledge are essential to good government," and that the board's action had "cut off the instrumentality by which those essentials to good government are cultivated." Bellamy Storer, another Methodist, noted that Christianity was "the prevailing religion in the State." But Judge Alphonso Taft's elaborate dissent maintained that government in religious matters "is neutral, and while protecting all [religions], it prefers none, and it disparages none." He differed with Judge Hagans over the meaning of the passage of the state constitution Hagans had cited; "When the [state's] Bill of Rights says 'religion, morality and knowledge being essential to good government," it did not mean "the Protestant Christian religion. That would be a preference, which the same section expressly disclaims, and emphatically forbids." Taft added that the use of the King-James Bible and the hymns and prayers at issue were clearly offensive to Jews, Catholics and agnostics, and, as such, he held that their use was an unconstitutional preference of one religion over another. To hold "that Protestants are entitled to have their mode of worship and their bible used in the public schools is to hold to the union of Church and State," a position "offensive to Catholics and Jews." ${ }^{\text {. }} 1$ Judge Taft, a Unitarian whose minister was almost certainly Thomas Vickers, was remembered by his Unitarian sons William Howard Taft and Horace Dutton Taft and his daughter-in-law Helen Taft as "lovable" because of his "wide tolerance" and "a strangely understanding sympathy for everybody." 82

The School Board appealed to the Ohio Supreme Court, which unanimously agreed with Taft that religious sectarian instruction should be "outside the true and legitimate province of government." Justice John Welch held for the court that governing bodies in Ohio had no right to spend taxpayer money to support religious instruction, "the very essence of tyranny" and "the first step in the direction of an "establishment of religion'." Each "sect" should "give its own instructions" elsewhere than in the public schools. Welch preferred "the doctrine of the Seventh Section of our own Bill of Rights, which I summarize in two words by calling it the doctrine of 'hands off'.' Let the state not only keep its own hands off, but let it also see to it that religious sects keep their hands off each other." ${ }^{, 83}$ Welch added this observation:

United with government, religion never rises above the merest superstition; united with religion, government never rises above the merest despotism; and all history shows us that the more widely and

\footnotetext{
${ }^{78}$ See Stephan Brumberg, "The Cincinnati Bible War (1869-73) and its Impact on the Education of the City's Protestants, Catholics and Jews," Hebrew Union College Journal 54 (April 2004), 11-46; Steven K. Green, The Bible, the School, and the Constitution: The Clash that Shaped Modern Church-State Doctrine (Oxford Univ. Press, 2011), 115; and Michael Perko, "The Building up of Zion: Religion and Education in $19^{\text {th }}$ Century Cincinnati," Cincinnati Historical Society Bulletin 38 (Summer 1980), 96-114.

${ }^{79}$ All 10 Catholic board members voted "yes"; 1 of the 2 Jewish members voted "yes"; and 11 of the 26 Protestant members voted "yes."

80 "The Bible in Schools," Christian Advocate, Nov. 18, 1869, p. 364, noted in Steven Green, The Second Disestablishment: Church and State in Nineteenth Century America (Oxford Univ. Press, 2010), "The School Question," 276-78.

${ }^{81}$ Robert G. McCloskey, ed., The Bible in the Public Schools: Arguments in the Case of John D. Minor, et al., versus The Board of Education of the City of Cincinnati, et al. (Cincinnati: Robert Clarke \& Co., 1870) (New York, DeCapo Press, 1964), x-xi, 357-416.See Stephan Brumberg, "The Cincinnati Bible War (1869-73) and its Impact on the Education of the City's Protestants, Catholics and Jews," Hebrew Union College Journal 54 (April 2004), 11-46; Steven K. Green, The Bible, the School, and the Constitution: The Clash that Shaped Modern Church-State Doctrine (Oxford Univ. Press, 2011), 115; and Michael Perko, "The Building up of Zion: Religion and Education in $19^{\text {th }}$ Century Cincinnati," Cincinnati Historical Society Bulletin 38 (Summer 1980), 96-114.

${ }^{82}$ Noted in Jonathan Lurie's biography, William Howard Taft: The Travails of a Progressive Conservative (Cambridge Univ. Press, 2012 ), 4.

${ }^{83}$ Board of Education v Minor, 23 Ohio State 211 at 240, 250 (1872). Welch's "hands off" remark was reiterated in the dissenting opinion of Justice Joseph B. Moore in Pfeiffer $v$ Board of Education, 77 NW 250 (Michigan, 1898).
} 
completely separated; the better it is for both.

Rutherford B. Hayes, Republican and Methodist from Cincinnati, campaigned successfully in 1875 for Governor of Ohio (a post he had held twice in the past) as a friend of the use of the King-James Bible in the public schools. As such, he excoriated Taft's views, as he would when campaigning as the Republican nominee in 1876 for the Presidency: "The proposition to banish the Bible from the schools," constituted "a blow" to "good government," since it prevented the schools from providing the "religion and morality" noted in the state constitution. It was thus "idle to urge that there will be "religion and morality' without the Bible." 84

Possibly inspired by the Ohio Court's embracing of Judge Taft's dissenting argument, three Protestant denominations developed dissenting voices of their own about the issue. While Presbyterian leadership continued to defend its use, leading Congregationalist, northern Baptist, and northern Methodist journals broke with their co-religionists in embracing the view taken by Taft in the Minor case. The voice of northern Baptists, The Baptist Quarterly, could see "no good and sufficient reason why the state should furnish to all people anything more than the rudiments of education." Similarly, Daniel Curry, editor of the northern Methodist Christian Advocate, a journal that had been critical of the Minor decision, now opined that bible reading, hymns and prayer were "outside the specific designs of the public school" and should not be "enforced against the protest of a minority....The inexorable logic of our whole American system of non-ecclesiastical politics requires that our public schools shall be secular and not religious." 85 This may explain the presence thereafter of some Methodist, Baptist and Congregationalist justices in the ranks of those following Taft's lead.

Wisconsin In 1889 a number of Catholic parents sought a writ of mandamus to direct the school board of Edgerton to halt the reading of the King-James Bible in the public schools. Their attorney cited a state statute that "no textbooks shall be permitted in any free public schools which would have a tendency to inculcate sectarian ideas." ${ }^{86}$ The district court's decision was appealed, and the high court of Wisconsin, speaking unanimously through Chief Justice William Penn Lyon, a Methodist (of Quaker heritage, as his name suggests), granted the writ. He noted that the court had taken "judicial notice" of the many immigrants to Wisconsin from Germany and Ireland, "among them...many Catholics and Jews." Lyon held the King-James Bible to be sectarian, and referred to both the state statute and to the virtually identical language in Article I, Section 18, of the state constitution. He maintained that the court was free to differ with the prior decisions of other state courts on the subject because this passage was "the first" of its kind in a state constitution to "expressly" prohibit such use of a religious object with sectarian characteristics. Explaining what he meant by this, Lyon asked, rhetorically, "is it unreasonable to say that the child of the Jew or Catholic, Unitarian or Universalist, or Quaker should not be compelled to listen to the...reading of passages of scripture which are accepted by others as giving the lie to the religious faith and belief of their parents and themselves?" Moreover, he held that the statutory granting of permission for a student unwilling to participate in such bible reading might be excused from the classroom was discriminatory and void: "From that moment the excluded pupil loses caste with his fellows, and is liable to be regarded with aversion, and subjected to reproach and insult.,

Justice John B. Cassoday, a Congregationalist who had successfully championed the right of women to practice law in Wisconsin, ${ }^{88}$ wrote a strongly worded concurring opinion, as did Justice Harlow Orton, both of whose grandfathers had been Baptist ministers. (Many Baptists were followers of the views of the $17^{\text {th }}$ century Baptist Governor of the colony of Rhode Island, Roger Williams, who favored the separation of Church and State.). Orton maintained that state entities, such as public schools, should avoid "all possible connection or alliance with any and all religions...and with everything of a religious character or appertaining to religion." The King James version of the Bible was "a source of religious and sectarian strife," and "hostile to the belief of many who are taxed to support the common schools, and who have equal rights and privileges in them.",89

\footnotetext{
${ }^{84}$ Quoted in Francis Abbot's The Index: A Weekly Paper Devoted to Free Religion, Sept. 7, 1876, 426.m

In 1925 the Republican-dominated Ohio legislature passed a bill requiring the use of the Bible in the public schools. The bill was vetoed by Catholic and Democratic Governor A. Victor Donahey. Donald E. Boles, The Bible, Religion, and the Public Schools (Iowa State University Press, 1961), 41, 238.

85 “The State and Religion,” The Baptist Quarterly, Jan. 1874, 77; “The Public Schools and the Churches," Christian Advocate, Dec. 2, 1875, 380; both cited in Steven Green's The Bible, the School and the Constitution, 191-92.

${ }^{86}$ Wis. Laws, 1883 , Ch. 251, Sec. 3.

${ }^{87}$ State ex rel. Weiss v District Board of Edgerton, 76 Wis. 177, 44NW 967, 30 American Law Register 286 at 301-303 (1890).

${ }^{88}$ Catherine B. Cleary, Lavinia Goodell: First Woman Lawyer in Wisconsin, 74 Wis. Mag. Hist. 243, 245 (1991); James Carper \& Thomas C. Hunt, The Dissenting Tradition in American Education (Peter Lang, 2007), 137.

${ }^{89}$ Weiss, 30 American Law Register 286 at 310 (Cassoday), 318-320 (Orton).
} 
The Weiss decision was condemned at a resolution of the Northern Methodist Church three weeks after it was handed down. Weiss was "un-American and pagan," and "a menace to the perpetuity of our institutions." A month later a Presbyterian conference adopted a resolution also condemning Weiss. But by 1890 there were Congregationalist (and Baptist) ministers who agreed with the views expressed in Weiss. ${ }^{90}$

\section{Wisconsin's Bennett Law}

The Weiss case was playing out in a larger, deeply related context: In April 1889 the Wisconsin legislature passed a bill that Republican Governor William Hoard, a Methodist lay-minister, had sought in his annual Message to the legislature. The statute came to be known as "the Bennett law," after Republican assemblyman Michael Bennett who had introduced the bill. It required twelve weeks attendance at a school for children between the ages of seven and fourteen "in the...[school] district in which he resides," such instruction in "reading, writing, arithmetic and United States history" to be "in the English language," and authorized the local school board to fine parents for noncompliance.

By 1890 some 37\% of Wisconsin's population had indeed hailed from Germany, as Justice Lyon had observed that is, the state census of 1890 indicated that $37 \%$ of the population were either born in Germany or had at least one parent born there. Still others in the population hailed from the German-speaking part of Austria-Hungary, and $7 \%$ hailed from Ireland. ${ }^{91}$ Both Catholic and Lutheran Germans in Wisconsin created their own private parochial schools, as they sought to raise their children in their native language. Moreover, as John Martin Henni, Archbishop of Milwaukee put it, Catholics felt attendance in the public schools "generally results in the ruin of the tender soul." 92

Wisconsin's Lutheran leadership soon met and objected to the Bennett Law, and both the Milwaukee Catholic Citizen and the state's three (German and Austrian) Catholic bishops criticized it as well. The bishops' "Manifesto" of March 13, 1890, declared that "after calm and careful study of the Bennett law we hold that it interferes with the rights of the church and of parents" in that its real intent was "to bring our parochial and private schools under the control of the state....and...gradually to destroy the parochial school system." ${ }^{.93}$ In April of that year George Peck, a Democratic opponent of the Bennett Law, was overwhelmingly elected Mayor of Milwaukee. The Madison Democrat viewed the statewide defeat of Republican candidates on their and their newsprint supporters having "Blained" the law (a reference to the failed "Blaine Amendment" of 1876, of which more below). The German language Wisconsin paper, Der Herold, declared the Democratic sweep as the "united opposition to attempts to create by legislative enactment a permanent conflict between church and state. The Bennett law was the cause of the Republican's defeat," and "the church has rebuked the state in its attempts its rights." ${ }^{94}$ That summer Christian Koerner, writing for Germania, a Lutheran publishing organization, styled the Bennett law "slavery worse than negro slavery" and "warfare against the German language and parochial schools." ${ }^{.95}$

In that same summer of 1890 Democrats chose Peck to challenge Hoard for the governorship. Hoard persisted in his support of the Bennett law, asking a meeting of public school teachers sarcastically why "Lutheran and Catholic clergy have suddenly become the only defenders of religion in the land," adding "where were the voices of his potential allies: "German Methodists, Baptists, Presbyterians, Scandinavian [here read Haugean evangelical] Lutherans and all that great body of English-speaking Protestants." ${ }^{.96}$ His call for evangelical assistance proved insufficient: Peck and Democratic legislative candidates won in November, and in early February 1891 the legislature's first action was to send to Governor Peck for engrossment the statutory repeal of the Bennett law. ${ }^{97}$

Oregon A similarly intended Oregon statute of 1922 required all children between 8 and 16 to attend public schools (where many of these schools had students read the King James Bible). Oregon, like Wisconsin, had a

\footnotetext{
${ }^{90}$ The decision was vigorously supported as well in The New York Times. See Steven K. Green, The Second Disestablishment: Church and State in $19^{\text {th }}$ Century America (Oxford Univ. Press, 2010), 316-17.

${ }^{91}$ Reports of the Immigration Commission. Statistical Review of Immigration, 1820-1910. Distribution of Immigrants, 1850-1900, III (Arno press, 1970), 522 .

${ }^{92}$ Quoted in Carper \& Hunt, Dissenting Tradition, 81

${ }^{93}$ Ibid., 89 .

${ }^{94}$ Quoted in translation in The Milwaukee Journal, April 2, 1890, p. 1.

${ }^{95}$ Christian Koerner, The Bennett Law and the German Protestant Parochial Schools of Wisconsin (Milwaukee, Germania Publishing Company, 1890), 9-18; cited in Carper \& Hunt, Dissenting Tradition, 101.

${ }_{96}$ Milwaukee Sentinel, April 3, p. 4.

${ }^{97}$ Carper \& Hunt, 102.
} 
large Catholic (albeit a smaller Lutheran) population, and Klansmen joined other anti-German Protestants in seeking to force Catholic and Lutheran parents to submit to the public school curriculum. Catholic Sisters of the Holy Name of Jesus and Mary operated a parochial school that was losing enrolment as a consequence of the law. They joined the directors of the Hill Military Academy, experiencing a similar loss, in challenging the law, but added that they objected to the infringement of the rights of Catholic parents to their liberty of conscience. A three-judge panel federal district court ruled in the plaintiffs' favor. Oregon appealed, and in 1925 the statute was struck down in Pierce $v$ Society of Sisters. ${ }^{98}$

Writing for the Court, Justice James McReynolds, a Democratic appointee, offered this "liberty of conscience" language obiter dicta" : "the Act of 1922 unreasonably interferes with the liberty of parents...to direct the education and upbringing of children under their control....The fundamental theory of liberty upon which all governments in this union repose excludes any general power of the State to standardize its children by forcing them to accept instruction form public school teachers only. The child is not the mere creature of the State..."

This case may be said to "close the circle" on our "four cousins-in-law," in that it linked substantive due process issues with bible reading ones.

Nebraska Nebraska's high court heard a case in 1902, State ex rel. Freeman $v$ Scheve et al., where a teacher had engaged students in bible reading, prayer and hymn singing. With one dissent, the court referred to Article 4, section 1 ("freedom of conscience"), and Article 8, section 8 ("no sectarian instruction"), of the state constitution to hold that requiring readings and recitations from the King James-version of the Bible, as well as prayer and the singing of hymns was constitutionally prohibited in public schools. Justice John H. Ames referred to the centuries-old disputes over the views of Luther, Wycliffe, Tyndale, and the Catholic Douay translations, and drew "direct attention" to Wisconsin's Weiss opinion ("that authority") in support of his majority view. ${ }^{100}$

Justice McReynolds makes a second appearance in this unit of our story, as the author of the lead opinion in Meyer v. Nebraska. ${ }^{1}$ Meyer involved a Nebraska law (c. 249, 1919), earnestly called for by the state's Ku Klux Klan, that prohibited the teaching of modern foreign languages before the $9^{\text {th }}$ grade in all Nebraska schools, but was not to interfere with religious instruction in those schools. Robert Meyer taught German in a Lutheran school, and was detected by the Hamilton County attorney reading in German during the noon hour to twelve elementary school students from a collection of biblical stories! Convicted under this law, he appealed to the Nebraska courts. In oral argument, his attorney, Arthur Mullen, an Irish Catholic Democratic Party civil liberties attorney, attributed the law to "hatred, national bigotry and racial prejudice engendered by the World War." The state's attorney told the Court that it had been "the ambition of the State to have its entire population 100 per cent American." Mullen failed in his attempt to obtain an injunction against enforcement of the law before Judge Good of the Nebraska district court for Hamilton County. Other Meyer attorneys lost again at the state supreme court level, but Justice Charles Letton bitterly dissented: "It is patent, obvious, and a matter of common knowledge that this restriction was a result of crowd psychology; that it is a product of the passions engendered by the World War." But Meyer secured a hearing before the U. S. Supreme Court, presented by Arthur Mullen. ${ }^{101}$ Justice McReynolds observed that "the real issue was the teaching of religion in foreign languages" aimed at the German Lutheran and Catholic schools in Nebraska, in that the English language instructional requirement had the immediate effect of reducing parochial school enrollments. This denied German Catholic and Lutheran parents their freedom of conscience by forcing their children into schools, many of which required the use of the King-James Bible. Mullen recounted that Justice McReynolds asked him in oral argument:

What about the power of the state to require children to attend the public schools? You will admit to that, will you not?

I do not admit that....I deny that a state can, by a majority of the legislature, require me to send my child to the public schools....It is striking down the principle that a parent has control over the education of his child.

Mullen then referred to practices in the Soviet Union:

98268 US $510(1925)$.

99 "Obiter dicta," because his ratio decidendi consisted of holding that the statute violated the substantive due process rights of parochial schools, which had lost enrolments as a consequence of the law. It had "taken" their "property" without due process.

${ }^{100}$ State ex rel. Freeman $v$ Scheve, 65 Neb. 853, 91 NW 846 (1902) at 847.

101 Mullen's name does not appear as counsel for the plaintiff in the Supreme Court report of the case, but he was awarded an honorary depress from Creighton University in his home state of Nebraska, which made note of his key role in that case, and if his claim then (and in his autobiography) to having provided oral argument to the Court was untrue, it would have been challenged by William G. Ross in his Forging New freedoms: Nativism, Education and the Constitution, 1917-1927 (University of Nebraska Press, 1994), where Mullen's account was noted. 
In Russia they abolished religious teaching altogether. There are 147 different languages in Russia; and you can not teach religion in any one of them over there.

That may have impressed McReynolds; he wrote the Court's majority opinion that the liberty guaranteed by the Due Process Clause of the Fourteenth Amendment included an individual's right "to contract, to engage in any of the common occupations of life, to acquire useful knowledge, to marry, to establish a home and bring up children, to worship God according to the dictates of his conscience, and generally to enjoy privileges, essential to the orderly pursuit of happiness by free men." He was joined in this opinion by Chief Justice William Howard Taft, a Unitarian, Justices Pierce Bulter, a Catholic and Democrat, Louis Brandeis, a Jew and Democrat, and Willis Van Devanter, a Republican. Justice George Sutherland, a Mormon and Republican, dissented. ${ }^{102}$

Illinois In 1910 the Illinois high court responded to "taxpayers" and Catholic parents in School District 24 on that school board's requirement that all students stand, assume "a devotional attitude," listen to readings of the King-James Bible, answer questions about the passages read, recite the Lord's prayer, and sing hymns. The court held that such acts of "compulsion to join in any form of worship," violated the state constitution's provision that no unit of the state aid "any church or sectarian purpose." "Prayer is always worship," wrote Justice Frank K. Dunn (a Republican whose party had declined to re-nominate him for judicial reelection in the late 1890s) for the majority, and the practice constituted "religious instruction." Illinois was not "a Protestant state," as the school board had argued. Perhaps "the majority of its people adhere to one or the other of the Protestant denominations," but that had no legal significance, because "the law knows no distinction between the Christian and the Pagan, the Protestant and the Catholic. All are citizens. Their civil rights are precisely equal." Justice John P. Hand dissented, insisting that "Illinois is a Christian state" and its citizens were "a Bible reading people." 103

Louisiana A Louisiana school board had required teachers to open school sessions with bible readings "without note or comment." One Catholic and two Jewish parents sued to halt the practice, citing articles of the Louisiana constitution, which stipulated that "every person has the natural right to worship God according to the dictates of his own conscience," and that "no public tax dollars be spent "in aid of any church, sect, or denomination of religion." 104 In March 1915 the judges of the state's $2^{\text {nd }}$ Circuit Court of Appeal certified the record of the case with questions for the state's high court, seeking “instructions." Justice Walter Somerville held for a unanimous court that the practice clearly violated the rights of Jewish taxpayers and was to cease. "Excusing such children on religious grounds...would work a discrimination against those who were excused. The exclusion of a pupil under such circumstances puts him in a class by himself; it subjects him to a religious stigma..." Justice Olivier Provosty's concurring opinion held that the conscience of Catholic taxpayers had been violated as well. ${ }^{105}$ Provosty was Catholic, and the population of Catholics in Louisiana outnumbered those of other denominations in the early $20^{\text {th }}$ century. ${ }^{106}$

Washington Washington's constitution contained articles virtually identical to those of Louisiana's. In 1918 Justice J. Stephen Chadwick, for Washington's supreme court, ruled in State ex rel. Dearle v Frazier that the practice by one school board of granting public school credit for the study of the King James version of the Bible violated Article 1, section 11, and Article 9, section 4, of the state's constitution, in that the practice used public funds for sectarian purposes. ${ }^{107}$ Chadwick cited Freeman $v$ Scheve, the Nebraska decision, extensively, and took issue with the "illogic" of decisions of other state courts that had sanctioned the use of that version of the Bible in public schools. ${ }^{108}$ Twelve years later that court heard the issue again in Clithero $v$ Showalter (1930). Clithero and thirty-six others had petitioned the state board of education to make Bible reading and instruction compulsory in the public schools. When the board declined doing so, the petitioners turned to the high court, which reiterated its view that Article 1, section 11, of the state constitution prohibited such practices and cited Dearle v Frazier. ${ }^{109}$

Georgia Members of the school board in Rome, Georgia, questioned whether that city's commission's mandate

\footnotetext{
102 See Meyer v State, 107 Neb 657, 187 NW 100 at 104 (Letton's dissent) (1922); Meyer v Nebraska, 262 US 390 at 399,400 (1923); and Arthur Mullen, Western Democrat (W. Funk, 1940), 214-226.

103 People ex rel. Ring v Board of Education of District 24, 245 Ill. 334, 92 NE 251 (1910).

104 Constitution of Louisiana, Article 1, section 4; Article 4, section 8; and Article 53.

105 Herold v Parish Board of School Directors, 136 La 1034, 68 So 116 (1915).

106 See fn. 122.

107 State ex rel. Dearle v Frazier, Supt. Of Schools, et al., 102 Wash 369, 173 Pac 35 (1918).

108 Referring especially State ex rel. Dearle v Frazier, Supt. Of Schools, et al., 102 Wash 369, 173 Pac 35 (1918), to the opinion of the Kentucky court, Hackett v Brooksville Grade School District, 120 Ky 608, 87 SW 792 (1905).

109 Clithero v Showalter, 159 Wash 519, 293 Pac 1000 (1930).
} 
that scripture from the King-James Bible be read to students daily by the principal or a teacher, followed by a prayer, "without discussion," was constitutional. ${ }^{110}$ The court majority was confident of the ordinance's constitutionality, but Justice James K. Hines dissented, maintaining that it broached the "natural and inalienable right of the individual to worship God according to the dictates of his own conscience." Hines regretted that he spoke "without the aid and comfort of a single one of my associates, but being committed with my whole soul to the doctrine of religious freedom, including freedom from molestation in matters of conscience," he quoted from the state's constitution in support of his claim that the ordinance "violates the rights secured by all of the above constitutional provisions; and therefore is unconstitutional and void." He also quoted Roger Williams: "No one should be bound to worship, or to maintain a worship [taxes to an established church] against his own consent." Hines noted that Catholic parents were permitted to request that their child be excused, but argued that "the exemption of certain classes from the operation of an unconstitutional enactment will not save its face." He insisted that the use of the King-James version of the bible "offends and molests the Catholic and Jews" as well as "certain sects of Protestants and deists, atheists, and agnostics." Moral instruction must, in Hines' view be "accomplished by methods keeping Church and State separate...." candidate for Governor of Georgia in 1894. He was a Methodist, but recall that by the 1920s that church was less evangelical in its tenets than it had been in the $19^{\text {th }}$ century.

Minnesota A school board had been asked by an association of Protestant ministers in the School District of Virginia, Minnesota, to place bibles in every public schoolroom, and to have the superintendent of schools have selections read daily "without comment." The King-James Bible was, as a matter of course, selected and the readings commenced, but with the provision that if a parent or student objected, the student might be excused from the classroom for the duration of the ten-minute reading. Several parents objected and brought suit. A majority of the high court jurists found no fault in the practice. Chief Justice Samuel B. Wilson dissented. He pointed out that in 1895 Minnesota's attorney general had issued a declaratory judgment calling the use of the King-James Bible in the public schools a violation of that state's constitution, and noted that "for more than thirty years" the school districts had restrained from employing it in the classrooms. Wilson regretted that this restraint had ceased, as the school board had violated the state constitutional guarantee to children in those schools (and their parents) that everyone could "worship God according to the dictates of his own conscience." The Board had imposed also a measure of "control or interference with the rights of conscience" that was specifically prohibited in Article I, section 16 and Article VIII, Section 3. Moreover, the chief justice argued that the mere act of excusing a child from the readings "makes him religiously conspicuous. It subjects him to religious stigma." Wilson referred favorably to the neighboring Wisconsin court's Weiss decision in the process. ${ }^{112}$

Colorado In People ex rel. Vollmar v Stanley, the court held that Bible reading was not sectarian, and that the option allowing uncomfortable students to leave the room was perfectly reasonable and lawful: "It is urged that to absent themselves for a religious reason 'subjects the pupils to a religious stigma and places them at a disadvantage.' We cannot agree to that. The shoe is on the other foot. We have known many boys [the year was 1927] to be ridiculed for complying with religious regulations, but never one for neglecting them or absenting himself from them." 113

Two justices dissented from the court's opinion because they disagreed with the majority's view that its use was not to be compulsory. In the dissenting view, no student should be permitted to leave the room! The jurist who authored that, Justice John T. Adams, a Presbyterian, Mason, Republican, and member of the Sons of the American Revolution, had spoken at a meeting of the rabidly anti-Catholic Ku Klux Clan in 1925 and was there lauded as "a great judge and a man of the highest integrity." "114 The concurring dissenter, Justice Greeley W. Whitford, a Republican, Methodist and Mason, had acquired notoriety while the U. S. district attorney for Colorado in securing convictions and jail terms for 15 striking Colorado's miners. ${ }^{115}$ Might they be characterized as King-James Bible "hard-liners?"

South Dakota My last chronological case, State ex rel. Finger v Weedman, 226 NW 348 (SD) (1929), concerned

\footnotetext{
110 The ordinance allowed students to be excused from these readings with a written request from a parent.

111 Wilkerson v City of Rome, 152 Ga 762 at 785, 786 (1922).

112 Kaplan v Independent School District of Virginia, 171 Minn. 142 at 155-56, 214 NW 18 at 23-24 (1927).

11381 Colo. 276, 255 P 610 (1927).

114 F. Swancara, "The Colorado Bible Case," 21 Lawyer and Banker 164 (1928).

${ }^{115}$ Congressional Serial Set: U. S. $64^{\text {th }}$ Congress, $1^{\text {st }}$ Session, Senate Document \# 415, Final Report... of Commission on Industrial Relations Volume 8 (Wash., GPO, 1916), “The Colorado Coal Miner’s Strike,” p. 7067.
} 
a school board rule that all students were required to attend readings of the King-James bible. Catholic parents sued. On appeal from a lower court ruling, the state's supreme court ruled 3 to 2 that while this was "a Christian nation," faith was a private matter, not to be mandated by the state. "We must take judicial notice, Justice Newton Burch, wrote for the majority, "of the character of the Bible and its meaning in this state" (which had a predominately Catholic and Lutheran ${ }^{116}$ population). He then quoted from the opinion in the Louisiana case ${ }^{117}$ : "To read the Bible for the purpose stated requires that it be read reverently and worshipfully." Burch cited Wisconsin and Nebraska ${ }^{118}$ high court language as well, and referred to the South Dakota constitution's "liberty of conscience" clause in holding the parents' liberty of conscience as "the controlling factor" in the court's decision. It reinstated the plaintiff's son in the school and directed the school board to permit children to absent themselves form bible readings. Chief Justice Sherwood dissented bitterly, citing John Appleton's views in Donahoe v Richards. ${ }^{119}$

All of the jurists upholding these in-school practices whose religion and/or political party affiliation could be identified were evangelical Republicans; most of those who opposed them as sectarian were Baptists, Quakers, Unitarians, or Catholics. ${ }^{120}$ And the religious populations that can be identified in several of the states at issue are consistent with the voting patterns just identified. Illinois, Wisconsin, South Dakota, and Nebraska, with large liturgical populations, as well as the state of Louisiana, with an even more significant Catholic population, had state supreme courts that held the King-James Bible and prayer readings to be sectarian and improper. Richard Jensen calculated estimates of the evangelical and liturgical population of those over the age of 10 for the year 1890 in six midwestern states, states where we have seen the issues of public school bible reading and school prayer had been litigated. By 1890 the liturgical population outnumbered the pietistic one in Wisconsin by a wide measure, and were of equal numbers in Illinois and Michigan evangelical church members were in the majority in Indiana, Ohio, and Iowa. ${ }^{121}$ And when we examine 1890 US Census data, we can see that the courts in Indiana, Iowa, Kentucky, Tennessee, Florida and Texas, with relatively small Catholic and significant evangelical populations, upheld these practices in their public schools, while those in Illinois, Louisiana, Nebraska, South Dakota, Washington and Wisconsin, each with relatively large Catholic populations, viewed them as unconstitutional. ${ }^{122}$ Not coincidences.

The number of state courts upholding the constitutionality of bible reading, outnumbered those holding it to violate state constitutions by a margin of two to one between 1854 and 1929 . And in the early $20^{\text {th }}$ century William T. Harris, the United States Education Commissioner, reported that about three of every four schools in cities of over four thousand inhabitants held bible readers or school prayer or both. ${ }^{123}$ However, the issue may have had an impact on other popular school public school texts, the McGuffey Reader and the Barnes Reader: Only $22 \%$ of the 1866 edition of the McGuffey Reader, and only $2 \%$ of the 1884 edition of the Barnes Reader were religious passages, and scholars who have studied such readers point to a steady decline in such religious content throughout the second half of the nineteenth century. ${ }^{124}$

\footnotetext{
${ }^{116}$ Of course many of the state's Lutherans were not confessional German Lutherans but Scandinavian evangelical Lutherans, and many German Lutherans did not object to that version of the bible. And all five members of the court were Republicans. But two of the three majority members, Burch and Campbell, were Freemasons, and the proportion of Democrats and potential objectors to the King-James version of the bible in the state was still very large.

117 Herold v Parish Bd., 136 La 1034, 68 SO 116 (1916).

118 State ex rel. Freeman $v$ Scheve, 65 Neb. 853, 91 NW 846 (1902).

119 State v Weedman, 226 NW 348 at 349, 354 (1929).

${ }^{120}$ Fast forward to 1990: Frank Sorauf detected the religion of the Louisiana Supreme Court justices in a case involving a statute offering state funds for teachers offering "secular" education in parochial schools (Seegers v Parker, 256 La. 1039, 241 So. $2^{\text {nd }} 213$ (1970)). The four Protestants on the court struck it down as unconstitutional; the three Catholics on the court voted to uphold it. Sorfauf, The Wall of Separation: The Constitutional Politics of Church and State (Princeton Univ. Press, 1976), 222.

121 Jensen, Winning of the Midwest, 87-88.

${ }^{122}$ Henry Gannett, U. S. Census Office, “Composition of Church Membership of the States and Territories: 1890.” Available online. Google: www.davidrumsey.com/luna/servlet/detail/RUMSEY 8 1 32013 1151361:35--Church-membership,-states-1890-?sort=Pub_Date\%2CPub_ List_No_InitialSort\&qvq=w4s:/who/Gannett,+Henry,+1846-1914/what/Statistical+Atlas;q:Country\%3D\%22United\%2BStates\%22\%2B;sort :Pub_Date\%2CPub_List_No_InitialSort;lc:RUMSEY 8 1\&mi=200\&trs=438 (accessed April 9, 2015)

Outliers: Maine, Massachusetts, Minnesota, and New York had relatively large Catholic populations in 1890. But the Maine decision was written in 1854, the Minnesota decision in 1927. Moreover, Justices on the Massachusetts Supreme Judicial Court were appointed, not elected.

${ }^{123}$ See Richard C. Wylie, Our System of Public Education: Is it Christian or Secular? (National Reform Documents, Allegheny City, Pa., 1901), 47

124 John Westerhoff, McGuffey and his Readers: Piety, Morality and Education in Nineteenth Century America (Abington Press, 1978); Richard de Charon and Gerald H. Moeller, "Values expressed in American Children's Readers, 1800-1950," Journal of Abnormal and Social
} 


\section{The Blaine Amendment}

As the Catholic population grew in cities like Boston, Cincinnati and New York, some Catholic prelates called for public funds to support Catholic parochial schools. In the early 1870s several state legislatures (including those of New York, Ohio and Missouri) adopted constitutional amendments barring the use of public funds for "sectarian" (here read "parochial") schools. ${ }^{125}$ Liberal Christian and Humanist leaders, led by Francis Ellingwood Abbot, founder of Index (a journal dedicated to the separation of Church and State) assailed the idea. Abbot organized a petition to the Congress in 1872 characterizing the notion as one that would "revolutionize the government of the United States and overthrow the great principles of complete religious liberty and the complete separation of Church and State on which it was established by its founders." 126

By 1875 the Bible issue was joined at the national level in the Congress with a proposed amendment to the Constitution, generally styled "the Blaine Amendment." 27 The idea of such an amendment, designed to bar public funds for parochial schools, was inspired by efforts of evangelical religious leaders, initially led by Presbyterians, organized as the National Reform Association. It was supported by evangelical figures like Supreme Court Justice William Strong, a Republican and devout Presbyterian, and Republican Congressman James G. Blaine. The groundwork was laid in 1875 when Ohio's Republican Governor Rutherford B. Hayes wrote to Blaine, Speaker of the House, on the "secret" power of "the school question" in Republican political plans. ${ }^{128}$ The two were on the same page as their Republican President, Ulysses S. Grant, who urged veterans of his Army of the Tennessee in late September, 1875, to "encourage free schools, and resolve that not one dollar, appropriated for their support, shall be appropriated to the support of any sectarian schools." He added: "Keep Church and State forever separate," ${ }^{, 129}$ but his primary objective was to prevent Catholic and German Lutheran parochial schools from ever receiving funds intended for public schools. ${ }^{130}$ His message to Congress of December 7, 1875, called for an Amendment that would deny public school funds to "any religious sect or denomination." 131

Blaine's ensuing House proposal forbad "the application of any public funds or property for the benefit of any school or institution under sectarian control." This was clearly aimed at Catholic and Lutheran parochial schools, and was added as a plank in the 1876 Republican Party platform. The Blaine proposal was adopted by the House and sent to the Senate. On August 11 the Senate Judiciary Committee, headed by Republicans, added to the Blaine House language, "This article shall not be construed to prohibit the reading of the Bible in any school or institution...."

The proposed amendment was embraced by Republican senators in the ensuing debate in that chamber, and criticized by Democratic senators who held that the proposal was chiefly aimed at Catholic schools, and would be "distasteful to the conscience of Hebrews and others." Democratic and French-Catholic Senator Lewis V. Bogy of Missouri charged his Republican colleagues with "partisan motives," the identification of the Democratic Party with Catholicism, and defended Catholic criticism of the public schools

for the reason that they were sectarian. Even the very Bible which [is] used in the schools [is] a sectarian book.... and being so, there is nothing strange or...remarkable that those who believed in their religion should not willingly sanction their children going where their religion was not only untaught but where they were really taught to believe it was not correct.

Similarly, New Jersey's Democratic Senator Theodore Randolph asked of the added Bible reading language: "Is

\footnotetext{
Psychology (Feb. 1962), 136-142

${ }^{125}$ Sister Marie Klinkhamer, “'The Blaine Amendment of 1875: Private Motives for Political Action,” 42 Catholic Historical Review (1957), 15-30.

${ }^{126}$ On Strong see Daniel G. Strong, "Supreme Court Justice William Strong, 1808-1895: Jurisprudence, Christianity and Reform," PhD dissertation, Kent State University, 1985) at 309-312. On Abbot see Phillip Hamburger, Separation of Church and State (Harvard University Press, 2002), 289-294.

127 A good introduction to this issue is Steven K. Green, "The Blaine Amendment Reconsidered," 36 American Journal of Legal History 38 (1992).

${ }^{128}$ Klinkhamer, at p. 21.

129 “Army of the Tennessee - A Speech by General Grant,” New York Tribune, Oct. 1, 1875, p. 1.

${ }^{130}$ One fine account of this Republican proposal is that of Noah Feldman, "Nonsectarianism Reconsidered," Journal of Law and Politics, 18 (2002), 65-118. Another, with dense explanations of its background and devolution is Steven K. Green, The Bible, the School and the Constitution: The Clash that Shaped Modern Church-State Doctrine (Oxford University Press, 2012), chapter 5, where he aptly observed (p. 180): The [Blaine Amendment] episode defies a simple accounting."

131 "The President's Message - Reforms for the Centennial Year," New York Tribune, Dec. 8, 1875, p. 1.
} 
not this a flat contradiction; or is the Bible a nonreligious book?" 132

On August 14, 1876, the Senate voted on the proposed Amendment; 28 Republican senators voted for it; 16 Democratic Senators, against it. ${ }^{133}$ The Amendment thus failed to secure the necessary numbers to be sent to the states, but Congress did pass legislation requiring those federal territories seeking statehood in the future to include language in their constitutions insuring that public schools would be "free from sectarian control," a measure again aimed at preventing the funding of parochial schools. Moreover, after the failure of the federal Blaine Amendment, some twenty additional states passed amendments to their state constitutions banning the funding of parochial schools. ${ }^{134}$

And that takes us to the U. S. Supreme Court's decisions on school prayer and bible readings.

\section{Engel and Schempp}

How might this tale of four "cousins-in-law" help us to understand the U. S. Supreme Court's actions with regard to certain church-state decisions in the 1940s and '50s? In 1940 the Court held in Cantwell v Connecticut 135 that the Constitution's Establishment of Religion Clause applied to the states. The federal entry into this issue produced two ensuing landmark cases: Engel and Schempp.

Let's begin with the latter case. In accordance with state law, ${ }^{136}$ the Abington School District in Pennsylvania required verses from the bible to be read to and by students at the beginning of every school day. Ellory Schempp, a Unitarian-Universalist, objected, and his father sued the District Board on his behalf, claiming his freedom of conscience had been denied him and that the reading of prayer violated the Establishment Clause of the First Amendment. The district court agreed, and the school district appealed the decision to the Supreme Court. Justice Tom Clark, former Attorney General in the Democratic Truman administration, wrote the majority opinion in Abington School District v Schempp. ${ }^{137}$ Clark referred to the views of both the "first" American Baptist leader, Roger Williams, and the dissenting opinion of Alphonso Taft in the Minor case, in holding that the School District and the Pennsylvania state legislature were acting in violation of Schempp's constitutional rights.

In a concurring opinion Justice William Brennan penned a review of the historical evidence on the subject, but concluded that "a too literal quest for the advice of the Founding Fathers upon the issues of these cases seems to me futile and misdirected." However, he offered an extensive footnote establishing psychological injury to students who suffer ostracism for having been excused from such exercises as bible reading sessions (which brought him to the same conclusion as had the Louisiana Supreme Court in Herold, Chief Justice Lyon in his Weiss opinion, and Chief Justice Samuel Wilson of the Minnesota Supreme Court in his dissent in Kaplan): ${ }^{138}$

The excusal provision of [the school board's] operation subjects them to a cruel dilemma. In consequence, even devout children may well avoid claiming their right and simply continue to participate in exercises distasteful to them because of an understandable reluctance to be stigmatized as atheists or nonconformists simply on the basis of their request. Such reluctance to seek exemption seems all the more likely in view of the fact that children are disinclined at this age to step out of line or to flout "peer-group norms. Such is the widely held view of experts who have studied the behaviors and attitudes of children.

Brennan reviewed prior case law, including many of the state cases from the $19^{\text {th }}$ and early $20^{\text {th }}$ century addressed in this essay, ${ }^{139}$ and concluded ${ }^{140}$ with a passage of the views of Pennsylvania's mid $19^{\text {th }}$ century Chief Justice, Jeremiah Black (a staunch Democrat who had been Democratic President Buchanan's Attorney-General and was baptized by Alexander Campbell, founder of the Disciples of Christ): ${ }^{141}$

\footnotetext{
132 Congressional Record, IV, pt. 1, (August 14, 1876), 5456, 5589-92; "Memorial Addresses on the Life and Character of Lewis V. Bogy (a senator from Missouri,) delivered in the Senate, January 161878 and in the House of Representatives, January 23 1878," pp. 11-12.

${ }^{133}$ Congressional Record, IV (August 14, 1876), Pt. 1, p. 5595.

${ }^{134}$ Feldman, "Nonsectarianism Reconsidered," supra note 108, pp. 65, at 96-107 19 sates), 110;; Green, Bible, School \& Constitution, 233 (21 states). This was in part checked by the Court's Pierce v Society of Sisters (268 US 510 (1925) decision which was struck down by an Oregon statute requiring all children between 8 and 16 to attend public schools.

135310 US 296 (1940).

13624 Pa. Stat. 15-1516, as amended, Pub. Law 1928.

137 School District of Abington $v$ Schempp, 347 US 203 (1963).

${ }^{138}$ Ibid., at 230, 237, 290-93, footnote 3/469. For Lyon's views in Weiss see fn. 85; for Wilson's views in Kaplan see fn. 106.

140 Ibid., p. 305.

${ }^{141}$ From his "Essay on Religious Liberty," in Black, ed., Essays and Speeches of Jeremiah S. Black (1886), 53.
} 
The manifest object of the men who framed the institutions of this country, was to have a State without religion, and a Church without politics -- that is to say, they meant that one should never be used as an engine for any purpose of the other, and that no man's rights in one should be tested by his opinions about the other. As the Church takes no note of men's political differences, so the State looks with equal eye on all the modes of religious faith. . . . Our fathers seem to have been perfectly sincere in their belief that the members of the Church would be more patriotic, and the citizens of the State more religious, by keeping their respective functions entirely separate.

Justice Potter Stewart, a Republican appointee, dissented.

Is it mere coincidence that Brennan was a Democrat and a Catholic, or that Stewart was a Protestant? Perhaps. But given what Phillip Hamburger and Donald Boles have told us of the "separation of church and state" views of nineteenth and twentieth century Baptist leaders ${ }^{142}$ it is not coincidence that Justice Hugo Black, author of the Court's opinion in the first of these cases, Engel $v$ Vitale, ${ }^{143}$ was a member in his hometown in Alabama of the Primitive Baptist Church (a traditional version of Baptist faith characterized in part by the views of Roger Williams ${ }^{144}$ ), and that he was a member of the five person Southern Baptist Convention's Committee on Public Relations in 1937. A few years after Black left the committee to take his seat on the high court, this Committee recommended that the Convention "enunciate, defend, and extend the historic, traditional Baptist principle of the separation of church and state." 145

This evidence goes a long way towards explaining Black's language in Engel where he wrote for the Court that the union of religion and government "tends to destroy government and denigrate religion," that "it is no part of the business of government to compose official prayers for any group of the American people to recite as part of a religious program carried on by the government, " and that it would "be neither sacrilegious nor antireligious to say that each separate government in this country should stay out of the business of writing or sanctioning official prayers and leave that purely religious function to the people themselves and to those the people choose to look to for religious guidance." 146

\section{Conclusion}

Of course, I have not elaborated on several other issues that evangelical organizations and the Republican Party (and, at times, Democrats in the South) raised and fought against in these same years at the local, state and federal level. These included (alphabetically listed) abortion, birth control, gambling/lottery tickets, obscenity/pornography, prizefighting, and Sabbath Day businesses and mail delivery. Let's limit our attention to these issues in this essay to political activities at the federal level. Gaines Foster was assisted by a number of his students at Louisiana State University in using the Congressional Record to code moral legislation bills introduced in the Congress between 1865 and 1920. The results appear in Table A1.3 in his useful study, Moral Reconstruction. ${ }^{147}$ On every one of these issues (including two that we have already visited: alcohol and polygamy) Republican legislators outnumbered Democratic ones in introducing such legislation, generally by

\footnotetext{
${ }^{142}$ Ranging from the views of Baptist ministers Rollin Neale and Thomas Curtis in the 1850s to Walter Johnson and Joseph Dawson in the 1920s and '30s. Hamburger, Separation of Church and State (Harvard Univ. Press, 2002), 282-282-84, 386-89; Boles, The Bible, Religion and the Public Schools, 211-13.

143 Engel $v$ Vitale, 370 US 421 (1962).

144 Roger Williams wrote of "a gap in the hedge or wall of Separation between the Garden of the Church and the Wilderness of the word" in Mr. Cotton's Letter Lately Printed, Examined \& Answered (1644) as well as a similar remark in his Letter to the Town of Providence (January $1655)$.

145 William W. Barnes, The Southern Baptist Convention, 1845-1953 (Broadman Press, Nashville, 1954), 299.

146 Engel v Vitale, 370 US 421 at 430-36(1962). Black quotes Roger Williams directly in fn. 20 to observations made on p. 435 : "What imprudence and indiscretion is it in the most common affaires of Life, to conceive that Emperours, Kings and Rulers of the earth must not only be qualified with politicall and state abilities to make and execute such Civill Lawes which may concerne the common rights, peace and safety (which is worke and businesse, load and burthen enough for the ablest shoulders in the Commonweal) but also furnished with such Spirituall and heavenly abilities to governe the Spirituall and Christian Commonweale . . . ." Similarly, in his dissent in Zorach v Clauson 343 US 306 at 319-320 (1952) Black wrote that the best policy "is by wholly isolating the state from the religious sphere and compelling it to be completely neutral.... State help to religion injects political and party prejudices into a holy field. It too often substitutes force for prayer, hate for love, and persecution for persuasion. Government should not be allowed, under cover of the soft euphemism of 'cooperation,' to steal into the sacred area of religious choice."

Sandy Levinson has speculated on the subject: ("It is possible that the methods of religious interpretation that [Black] learned as a child (the Clay County Primitive Baptist Church) influenced his constitutional methodology as a justice") in "The Constitution in American Civil Religion," The Supreme Court Review 1979, 123 at 133 in footnote 41.

147 Foster, Moral Reconstruction: Christian Lobbyists and the Federal Legislation of Morality, 1865-1920 (University of North Carolina Press, 2002), 239.
} 
very wide margins.

The only issues that attracted significant Democratic support, and then only among Southern Democratic legislators in the twentieth century, were alcohol and gambling/lottery ticket sales, and on the latter of these, southern Democratic House congressmen voted overwhelmingly (49 to 13) to block such lottery ticket legislation at one critical juncture. (Arkansas Democratic senator John Rogers served on the Senate Post Office Committee. He remarked in debate on a bill that would ban advertisements for the sale of lottery tickets by mail, that it would give "the Postmaster-General [power] to destroy [or] impair as much as he can...[legal state] institutions because Congress regards such institutions as immoral to coerce the states to adopt the standard of Congressional morality.", ${ }^{48}$ ) What must be kept in mind is that, in these years, there was no effective Republican Party in the South. Consequently, evangelical politicians there had to be members of the Democratic Party if they had any chance of being elected. This explains the presence of several evangelical southern legislators. Thus Foster's findings are essentially consistent with those presented in this essay.

Application of the findings of historians of American politics in the 1970s and '80s, then called "the new political history," help to explain the voting positions of state and federal legislators and jurists in the 1850s and thereafter. Historian Charles Beard once pithily observed that in the United States "economics becomes politics, and politics in turn become constitutional law."149 It can with equal justice be observed that in the United States, moral/religious issues also become politics, and these politics in turn also become constitutional law.

\section{Copyrights}

Copyright for this article is retained by the author(s), with first publication rights granted to the journal.

This is an open-access article distributed under the terms and conditions of the Creative Commons Attribution license (http://creativecommons.org/licenses/by/3.0/).

\footnotetext{
148 Foster, Moral Reconstruction, Table A1.4, p. 240, and (on lottery ticket sales) at p. 121-122.

${ }^{149}$ Charles A. Beard, Economic Origins of Jeffersonian Democracy (Macmillan, 1915), 217.
} 